\title{
Study of coliforms and Clostridium bacteria inactivation in wastewaters by a pilot photolysis process and by the maturation lagoons of a low-cost nature-based WWTP
}

\author{
Juan Carlos García-Prieto ${ }^{1}$ (1) · Cynthia Manuela Núñez-Núñez ${ }^{2}$ (D) José Bernardo Proal-Nájera ${ }^{2}$ (I) . \\ Manuel García-Roig ${ }^{1}$
}

Received: 27 July 2021 / Accepted: 14 December 2021 / Published online: 20 January 2022

(C) The Author(s) 2022

\begin{abstract}
The inactivation processes of coliform bacteria (total and fecal) and sulphito-reducing Clostridium bacteria (vegetative species and spores) in water maturation lagoon of a low-cost nature-based wastewater treatment plant using constructed wetlands and through processes of photolysis in a pilot photoreactor have been comparatively studied. The different inactivation mechanisms by photolysis of these bacteria have been studied following the criteria of different statistical and kinetic models. Clostridium disinfection treatments fit models in which two types of bacteria populations coexist, one sensitive (vegetative species) and the other (spores) resistant to the treatment, the sensitive one (94\%) with an inactivation rate of $k=0.24 \pm 0.07 \mathrm{~min}^{-1}$ and the resistant one (6\%) with $k=0.11 \pm 0.05 \mathrm{~min}^{-1}$. Total coliform photolytic disinfection also shows two populations with different physiological state. The time required to reduce the first logarithmic decimal cycle of the different types of bacteria (physiological states) are $\delta_{1}=4.2 \pm 0.9$ and $\delta_{2}=8.3 \pm 1.1 \mathrm{~min}$, respectively. For fecal coliform photolytic disinfection, only bacteria population, with $k=1.15 \pm 0.19 \mathrm{~min}^{-1}$, is found. The results obtained confirm the photolytic disinfection processes and maturation lagoon are effective systems for Clostridia bacteria removal after water treatment by nature-based systems. Total removal of coliform bacteria is not achieved by maturation lagoons, but their reduction is significant using low doses of cumulative radiation.
\end{abstract}

Keywords Photolysis · Wastewater · Disinfection/inactivation · Endospores · Clostridium · Coliforms · Maturation lagoons · Constructed wetlands

Responsible Editor: Sami Rtimi

Manuel García-Roig

mgr@usal.es

Juan Carlos García-Prieto

jcgarcia@usal.es

Cynthia Manuela Núñez-Núñez

cynthia.nunez@unipolidgo.edu.mx

José Bernardo Proal-Nájera

joseproal@hotmail.com

1 Centro de Investigación y Desarrollo Tecnológico del Agua (CIDTA), Universidad de Salamanca, Campus Miguel de Unamuno, Facultad de Farmacia, Campo Charro s/n, 37080 Salamanca, Spain

2 CIIDIR-Unidad Durango, Instituto Politécnico Nacional, Sigma 119, Fracc. 20 de Nov. II, 34220 Durango, Dgo, Mexico

\section{Introduction}

The inactivation of microorganisms by ultraviolet radiation has been known for more than 100 years (Downes and Blunt 1877). The factors affecting the germicidal action of ultraviolet light (photolysis) depend on the absorption by the microorganisms of the appropriate electromagnetic energy (wavelength and irradiation power), which in turn depends on the properties of the fluid itself and the substances present in the fluid such as suspended solids, which can absorb part of this electromagnetic radiation (Lorch 1987). This electromagnetic energy affects the genetic material of the organism (DNA and/or RNA), so that the microorganisms cannot replicate and, therefore, die (Bolton and Linden 2003). An important aspect in the efficiency of this process is the existence of nucleic acid repair mechanisms called photoreactivation or photo repair (Groocock 1984; Guo et al. 2013), in which a photoreactive enzyme, after absorbing 
radiation, is able to repair the damage caused. This regenerative capacity occurs in bacteria and other microorganisms, but not in viruses, and its performance is related to the extent of UV damage, exposure to reactivating light, $\mathrm{pH}$, and water temperature (Masschelein and Rice 2002). The photoreactivation phenomenon will require that the exposure of the microorganism to the reactivating light does not exceed 2 to $3 \mathrm{~h}$ after inactivation, taking into account that the degree of reactivation is a function inversely proportional to the radiation dose used.

Nowadays, nature-based wastewater treatments are an important alternative in the field of wastewater disinfection strategies to reduce pathogenic species that affect health (Vymazal 2005; Wu et al. 2016; Huang et al. 2018) and agricultural wastewater reuse (Masi and Martinuzzi 2007; Almuktar et al 2018; Nan et al. 2020). Furthermore, disinfection is required in some areas to fulfil certain directives, such as the Habitats Directive (92/43/EEC) and Bathing Water Directive (2006/7/EC). The level of disinfection of microorganism is insufficient in constructed wetlands (López et al. 2019), which is why some authors propose the use of UV photolytic reactors (Azaizeh et al. 2013; González et al. 2019) and others the use of maturation lagoons (Tanner et al. 2005; Russo et al. 2020).

Bacterial cells have always been described as an easy target for the study of disinfection and the selected microorganisms (Coliforms and Clostridia) to monitor the process are the major groups of bacteria covered by the regulation relating to water for human consumption (Gorchev and Ozolins 1984). On the one hand, coliform bacteria such as Escherichia coli are the most commonly used indicators of fecal contamination in drinking and wastewater regulations (Ashbolt et al. 2001). These Gram-negative bacteria inhabit the intestinal tract of humans and warm-blooded animals. Their presence in water is not only indicative of fecal contamination, but also of the presence of other possible enteric pathogens such as Salmonella spp., Yersinia spp., and Shigella spp. These enteric bacteria are responsible for minor gastrointestinal diseases (Dekker and Frank 2015).

On the other hand, the microorganisms such as sporeforming bacteria and protozoa, used as target organisms, have been shown to be much more resistant to disinfection (WHO 2011). For this reason, few articles have focused on these spore-forming bacteria, such as Clostridium, which have greater resistance to disinfection treatments (Dolin 1959; Ando and Tsuzuki 1986; Lanao et al. 2010). Given the extraordinary resistance of Clostridium spores to disinfection processes and other adverse environmental conditions, their presence in disinfected waters may indicate that the treatment has been deficient and perhaps other resistant pathogens have also survived (Payment 1999); hence the European Directive 98/83/EC proposed this species as an index of the presence of enteric protozoa and viruses in treated drinking water. Consequently, sporulating bacteria of the genus Clostridium have been used as indicators of the efficiency of the disinfection process (Josset et al. 2008). These bacteria are Gram-positive, anaerobic, sulphito-reducing bacilli that produce spores that are exceptionally resistant to adverse conditions in aquatic environments, including UV irradiation, extreme temperatures, and $\mathrm{pH}$, and disinfection processes such as chlorination (Venczel et al. 1997; Dunlop et al. 2008). Like E. coli, Clostridium does not proliferate in most aquatic environments, making them very specific indicators of fecal contamination, thus being highly distributed in the environment and present in natural waters and soils. They are generally originated from human and animal fecal matters, especially present in wastewaters discharged into receiving waterways; hence they may represent a sign of remote or intermittent contamination (Talukdar et al. 2016). In addition, other authors indicated that climatic factors such as ambient temperature, rainfall, and relative humidity affect the incidence of these microorganisms. Hence, the rates of diseases could be influenced by climate change (Park et al. 2018; Oh et al. 2021).

Disinfection in constructed wetlands have different influencing factors, such as water composition, seasonal fluctuations, and local vegetation and whether fecal waste from wild birds and other animals add significantly to the total from human waste (Rahman et al. 2020). This means low-cost naturebased wastewater treatment plants cannot provide standardized performance, unlike conventional treatment plants. The pathogen removal mechanisms are also complex-most frequently including natural die-off due to starvation or predation, sedimentation and filtration, and adsorption (Alufasi et al. 2017). Therefore, it is therefore difficult to assess wetlands performance on average. In this work, the feasibility and performance of the photolysis for the inactivation of Coliforms and Clostridia bacteria and their spores in urban wastewaters after their treatment by low-cost nature-based wastewater treatment plants have been studied. For this, photolysis process in a pilot reactor and maturation lagoon in series with constructed wetlands has been used for this purpose.

\section{Materials and methods}

\section{Photoreactor with total recirculation}

The photoreactor used is shown in Fig. 1. The system has a tank for the sample with a capacity of $200 \mathrm{~L}$, a pump of 1 $\mathrm{hp}$ for recirculation of the sample in the system, and at the outlet of the pump, the water passes through a $50-\mu \mathrm{m}$ solid filter and then through a rotameter to measure the sample flow entering the reactor body. 


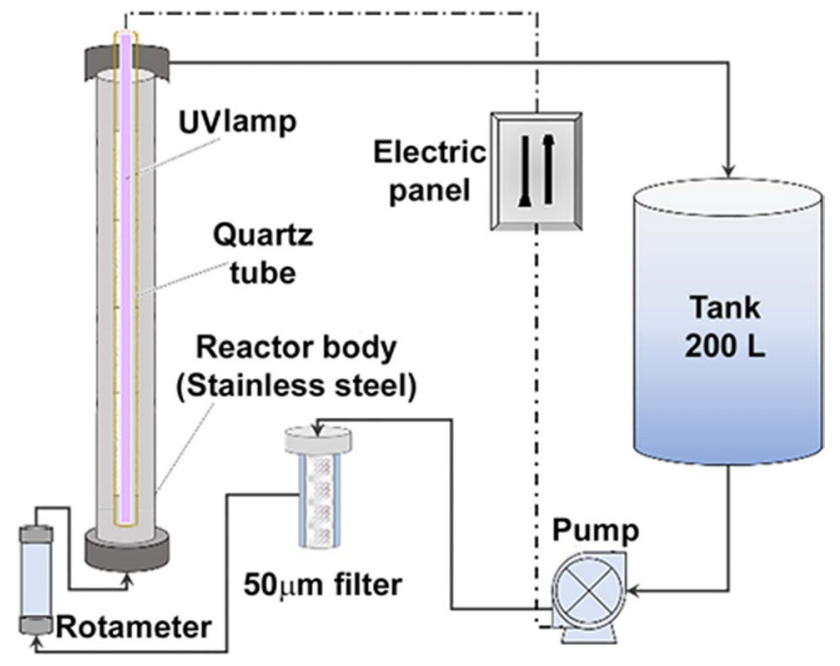

Fig. 1 Reactor system used for photolytic inactivation processes

The reactor is characterized by maintaining a vertical piston flow with bottom inlet and upper lateral outlet; the reactor body is made of stainless steel and has a manometer on the bottom and another on the top. A $40 \mathrm{~W}$ Philips lamp emitting $15 \mathrm{~W}$ of ultraviolet radiation was used as irradiation source. The lamp was placed inside a transparent quartz tube to prevent it from entering in contact with the sample.

\section{Bacteria sampling, growth, sporulation, and analysis}

For the study of the inactivation of Coliforms and Clostridium bacteria, aliquot samples were taken from the effluents of the wastewater treatment plant (WWTP) of the municipality of Monleras, belonging to the province of Salamanca, Spain, with geographical location coordinates $41^{\circ} 11^{\prime} 11.99^{\prime \prime}$ North, $6^{\circ} 14^{\prime} 04.21^{\prime \prime}$ West, was chosen as low-cost naturebased WWTP. Primary treatment is carried out in an Imhoff tank for the decantation of solids and digestion of organic matter. Secondary treatment is initially carried out in a horizontal wetland of macrophytes in flotation with other aquatic plant species, and then the water is sent to three parallel vertical subsurface flow wetlands, where the water percolates vertically through an inert substrate of sand and gravel, and finally the water reaches an artificial wetland that functions as an aerobic maturation lagoon, due to its shallow depth, for the disinfection of the water by the effect of sunlight (Arco-Alaínez 2014). This plant was designed by CIDTA's authors, and this design was chosen by the Duero Watershed Confederation (Spain) to finance its construction within the framework of its pilot project "Singular experimental treatment of sewage discharges in small towns in the Duero river basin" (García-Prieto and Cachaza Silverio 2008).
The coliform bacteria count was carried out by the pour plate method (APHA 1995), using Chromogenic agar (Scharlau, Spain), which contains nutrients to give coloration and allows to differentiate between fecal coliforms $(E$. coli) and other coliform microorganisms present in the sample. After $24 \mathrm{~h}$ of incubation at $37{ }^{\circ} \mathrm{C}$, a visual count of the colonies was made in each plate, considering as fecal coliforms colonies those of purple coloration and as other coliforms, those that showed pink to red coloration, the total coliforms count results from the addition of fecal coliforms colonies and those of other coliforms present. As culture media for the growth and determination of Clostridium, iron agar and modified sulfite agar, both from SCHARLAU, were used. The culturing and counting of vegetative cells and spores of Clostridium perfringens are carried out following the procedure described in the Spanish Standard UNE-EN 26,461 (AENOR 2009).

\section{Experimental procedure}

The control of the parameters involved in the determination of the inactivation efficiencies by photolysis was carried out. For each experiment, a $50 \mathrm{~L}$ wastewater sample from the wastewater treatment plant (Monleras) was deposited in the feed tank of the photoreactor (Fig. 1). The pump was adjusted to a recirculation flow rate of $1000 \mathrm{~L} / \mathrm{h}$; the temperature was $25{ }^{\circ} \mathrm{C}$ and in three aliquot samples, taken at each different time of the inactivation process; the colonyforming units per $\mathrm{mL}(\mathrm{CFU} / \mathrm{mL})$ of bacteria were counted.

\section{Data analysis}

To obtain the kinetic parameters of each model proposed for bacteria inactivation processes, it is necessary to fit the experimental kinetic data to the corresponding rate equation of the model by non-linear regression techniques. The model parameters are fitted to equations using iterative algorithms based on the least squares method. The statistical package SimFIT (Bardsley 2017) and GInaFiT (Geeraerd et al. 2005) will be used to obtain model parameters. The experimental data represent the average number of colony-forming units per $\mathrm{mL}(\mathrm{CFU} / \mathrm{mL})$, counted at each time on triplicate samples, along the kinetic runs. To evaluate how well the model fits the experimental data obtained, in addition to the plotting of the real data along the fitting curve, two indicators are used, the coefficient of determination $\left(R^{2}\right)$ which provides a measure of how well observed outcomes are replicated by the inactivation model, based on the proportion of total variation of outcomes explained by the model, the closer to unity, the better the fit, and the root mean sum of squared error (MSE), which measures the average squared difference between the estimated values and the actual value, so the closer to zero, the better the goodness of fit. The kinetic parameters of bacteria inactivation in the different water samples by the photolysis processes were determined. 


\section{Results and discussion}

\section{Sampling tests}

Several factors affect the susceptibility of microorganisms to photolytic processes. Previous studies show that it is very difficult to extrapolate the results obtained with synthetic wastewaters to real wastewater, since the growth stage of the bacteria and the synergy existing between the different microbial species present in the effluent strongly influence the results of the application of photolysis processes (Rincón and Pulgarin 2004, Rincón and Pulgarin 2007). The annual monitoring study of the main physicalchemical characteristics of Monleras WWTP wastewater samples and global UV radiation (direct and diffuse) (AEMET 2020) is shown in Fig. 2. Regarding the $\mathrm{pH}$, the $\mathrm{pH}$ of water samples from the macrophyte wetland was 6.5-7.0, and the $\mathrm{pH}$ of waters from the maturation pond was between 7.23 and 7.95 , throughout the year. In this sense, some researchers reported that the photochemical elimination of coliform bacteria was not affected by the $\mathrm{pH}$ of the solution in the range of $\mathrm{pH} 6.0-8.0$ (Watts et al. 1995; Cho et al. 2004).

In the case of the photolytic reactor, UV rays are predominantly emitted perpendicular to the lamp surface. To determine the radiation intensity on a surface at different distances, the intensity of the lamp at $1 \mathrm{~m}$ must be multiplied by the intensity factor with distance. According to the data provided by the lamp manufacturer (Koninklijke Philips), the $15 \mathrm{~W}$ lamp has a global UV irradiance of $144 \mu \mathrm{W} / \mathrm{cm}^{2}$ at a distance of $1 \mathrm{~m}$. The irradiated energies at different distances within the photolytic reactor are shown in Fig. 3.

The biocidal effect of sunlight is due to the synergistic effect between radiation and temperature. Sunlight is absorbed by natural photosensitizers present in water that react with oxygen to produce highly reactive molecules such as hydrogen peroxide and superoxide ion (Khaengraeng and Reed 2005; Heaselgrave and Kilvington 2010).

Under these conditions, wastewater samples were taken in May to July (red shading Fig. 2), when optimal climatic
Fig. 2 Wastewater physicochemical parameters and UV radiation characterizations at the municipal wastewater treatment plant (Monleras, Salamanca, Spain)
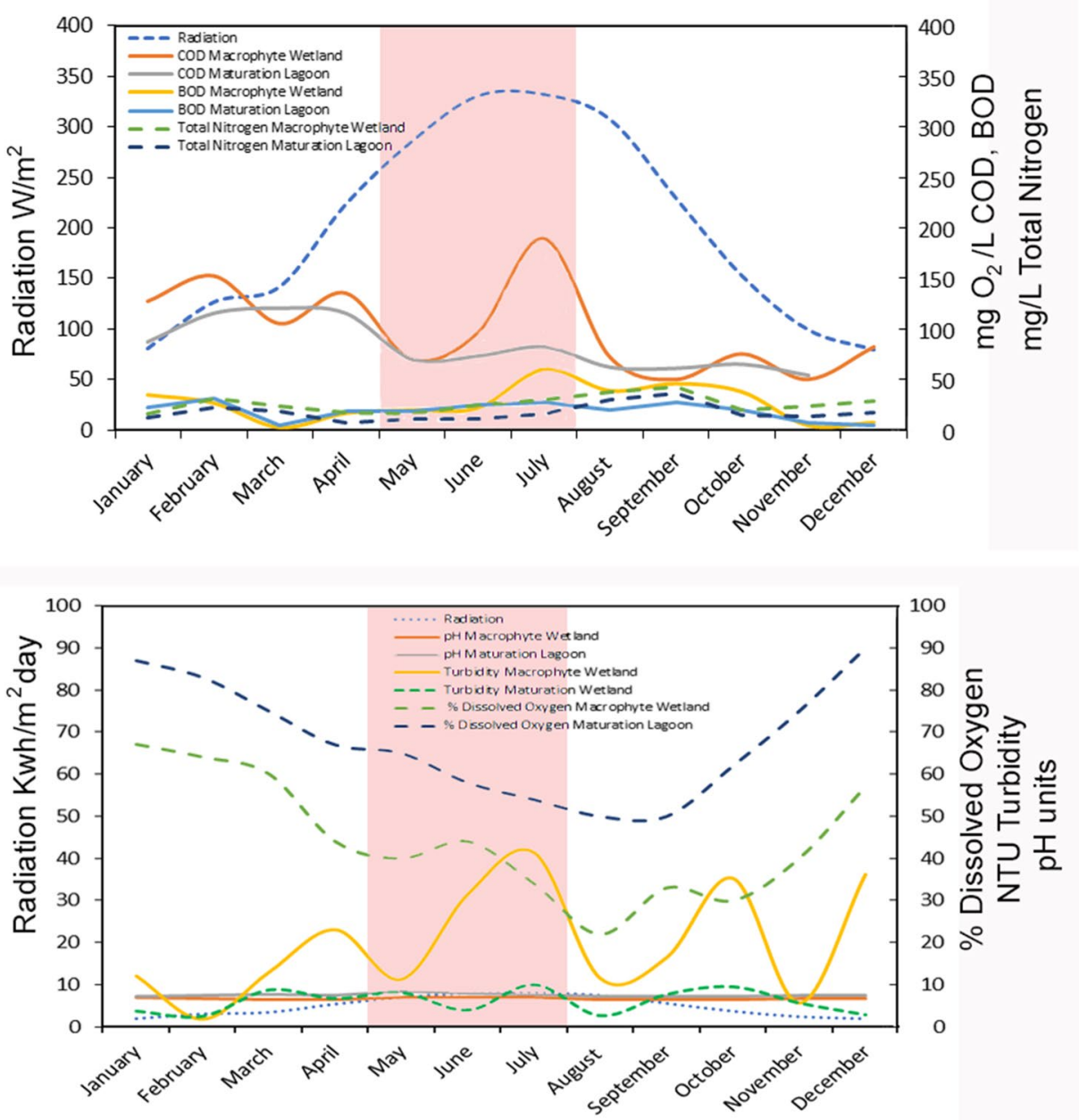


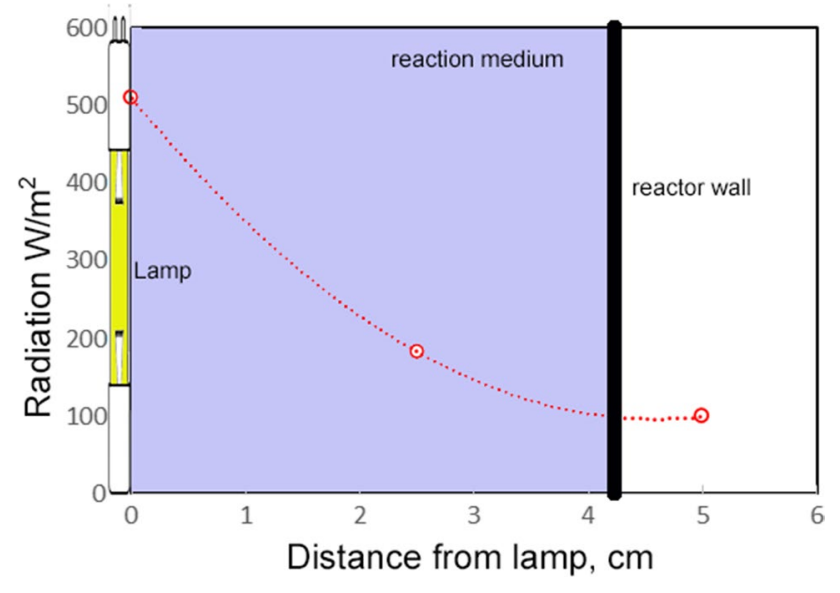

Fig. 3 Distribution of UV lamp irradiation inside the reactor

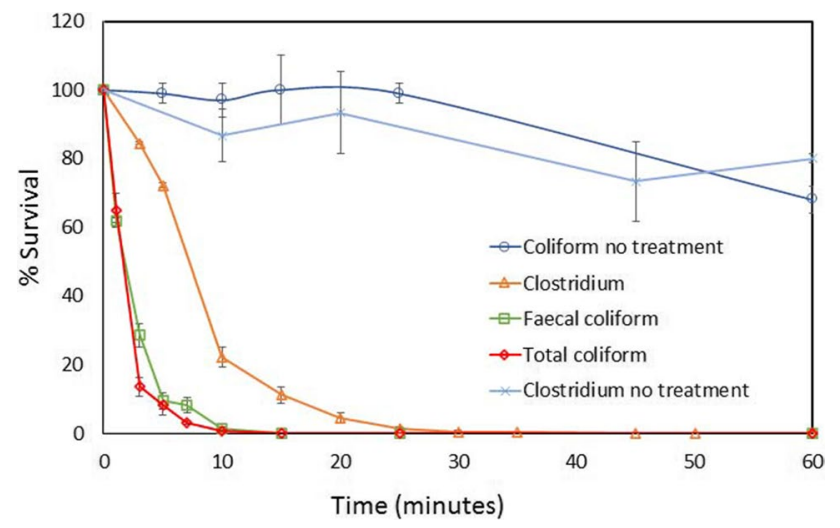

Fig. 4 \% Survival bacteria in wastewater samples from the Monleras WWTP subjected to photolysis and no light irradiation within the reactor

conditions exist for the reproduction of these microorganisms and the overall UV radiation conditions are more similar to the radiation emitted by the lamp in the photolytic reactor. These bacterial inactivation processes in the tertiary wetland (maturation lagoon) of Monleras WWTP to pilot photolytic reactor were compared.

\section{Kinetics of bacteria inactivation processes in wastewaters treated by nature-based treatments}

In the first place, the bacteria removal effect of the $50-\mu \mathrm{m}$ filter of the reactor circuit on the bacteria present in the wastewater samples was tested. For comparative purposes, bacteria $(\mathrm{CFU} / \mathrm{mL})$ were counted in kinetic experiments carried out in the photoreactor for $60 \mathrm{~min}$ with macrophyte wetland of Monleras WWTP effluent samples (1) in absence of UV radiation (without lamp with filtering effect), and (b) with UV light irradiation (photolysis with filtering effect) (Fig. 4). It can be seen that the CFU/mL remained in the order of $20 \%$ in the "no treatment" experiments, which shows that the filter do not reduce the initial concentration order on their own in the reactor. It is observed how the inactivation kinetics of bacteria in the wastewater samples treated by photolysis are fast and efficient, reaching a $100 \%$ inactivation performance of the bacteria present in about 25 min of treatment.

\section{Kinetic modeling of photolytic processes of microbial inactivation}

Different kinetic models have been proposed in the literature to explain microbial disinfection processes by photolysis under ultraviolet irradiation (Dalrymple et al. 2010). The first kinetic models described for ultraviolet disinfection are based on the Chick-Watson model (Chick 1908), which proposed a first-order model according to the following differential and integrated rate equations:

$\mathrm{r}=-\frac{\mathrm{dN}}{\mathrm{dt}}=-\mathrm{kCN}$

$\operatorname{Ln} \frac{N_{t}}{N_{o}}=-k C^{n} t==-k I t$

where $N$ is the concentration of viable organisms (CFU/100 mL) after exposure to UV light, $N_{o}$ is the concentration of viable organisms (CFU/100 $\mathrm{mL}$ ) before exposure to UV light, $k$ is the first-order rate constant, $C$ is the concentration of disinfectant, and $n$ is the number of disinfectant molecules required for microbial inactivation.

In the case of photolytic processes, these simple kinetics assume that all microorganisms in the population have the same sensitivity to the lethal agent, so when their inactivation is plotted versus treatment time, under a constant light irradiation power (I), a straight line would be obtained (pseudo-first order kinetics), but it is known that in real conditions this behaviour can present shoulder and tail deviations (Gyürek and Finch 1998).

Several theories develop alternative kinetics that allow describing non-linear survival curves (Hom 1972; Cerf 1977; Geeraerd et al. 2005). Kinetics curves showing initial shoulder or lag phase deviations indicate that a fraction of surviving microorganisms remains constant in the first instants of treatment, followed by a linear decrease in the number of surviving microorganisms. This is attributed to an inadequate distribution of the UV light through the sample, a delay in the diffusion of the UV light to the bacterial action sites or an initial resistance of the microorganisms to the attack of the disinfectant agent. Tailing-off curves are characterized by an initial rapid linear inactivation phase followed by a slow population decline. 
The inactivation kinetics curves that typically show an initial shoulder type deviation (Geeraerd et al. 2000) are adapted to a logarithmic-linear model with one shoulder, indicating that a fraction of surviving microorganisms remains constant in the first instants of treatment, followed by a linear decrease in the number of microorganisms. This model is defined by the equation:

$N_{t}=\left(N_{o}-N_{r e s}\right)\left(\left(e^{-k_{\max } t}\right) \cdot\left(\frac{e^{k_{\max } S}}{1+\left(e^{k_{\max }}-1\right) \cdot e^{-k_{\max } x}}\right)+N_{\text {res }}\right.$

where $k_{\max }$ is the specific inactivation rate constant, $N_{\text {res }}$ is the residual population density, and $S$ is the initial stress resistance.

As in the case of the shoulder phenomenon, there are several theories about the occurrence of tails. It may be due to microorganism clusters, to the presence of subpopulations with variable resistance to the disinfectant, either innate or in response to an adaptation to the environment, or also, to a decrease in the concentration of the disinfectant during treatment. There are sigmoidal curves with both linear deviations, showing an initial shoulder phase followed by a linear inactivation phase and ending with a tailing phenomenon.

Mafart et al. (2002) propose the use of Weibull statistical distributions to develop models that include both convex kinetics, with an initial period of no apparent inactivation, and concave kinetics where complete inactivation is not achieved. The Weibull frequency distribution model is based on the distribution of probability designed to describe the behavior of systems that have a certain degree of variability, assuming that microbial populations are heterogeneous in terms of resistance and that each cell requires different conditions to die. Mafart's model is given by the equation:

$\log \frac{N_{t}}{N_{0}}=-\left(\frac{t}{\delta}\right)^{P}$

where $\delta$ is the scale parameter and corresponds to the time required to reduce the first logarithmic decimal cycle of the bacterial population and $p$ is the shape parameter and indicates the shape of the equation curve, since it takes convex shapes when $p$ is greater than 1 and concave when it is less than 1. This model is based on thermal inactivation models and has been used to describe the disinfection on different types of microorganisms in photoreactors, as well as the operational parameters in photolysis (Gomes et al. 2009).

There are two models that describe sigmoidal curves of inactivation; i.e., they describe the behavior of microorganisms when shoulder phenomena, a linear inactivation phase, and tail occur. These models are the biphasic model with shoulder (Geeraerd et al. 2005) and the mixed model of two Weibull-type statistical distributions (Coroller et al. 2006).

The biphasic model with shoulder considers two groups in the microbial population, one having initial stress resistance (shoulder), an initial protection that is gradually destroyed, and a second more resilient population group based on vitalistic or mechanistic models. The vitalistic concept refers to the notion that individuals within a population are not identical and are grouped into populations. This would explain the different UV resistance of microorganisms. The second is a mechanistic concept, which assumes that microorganism inactivation processes are analogous to chemical reactions, which can occur through different pathways (Cerf 1977). The integrated rate equation of the biphasic model is the following:

$\log \frac{N_{t}}{N_{o}}=\log \left(\left(f \cdot e^{-k_{1} t}+(1-f) \cdot e^{-k_{2} t}\right) \cdot \frac{e^{-k_{1} S}}{1+\left(e^{-k_{1} S}-1\right) \cdot e^{-k_{1} t}}\right)$

where $N t$ represents the bacterial concentration at time $\mathrm{t}, \mathrm{No}$ is the initial concentration of microorganisms $(\mathrm{CFU} / \mathrm{mL}), \mathrm{t}$ is the time, $f$ is the fraction of the initial population following the fast reaction, and $(1-f)$ is the fraction of the initial population following the second phase of the reaction, where $k_{1}$ is the rate constant of the sensitive population and $k_{2}$ is the rate constant of the resistant population. The parameter $S$ is the time of the shoulder effect, i.e., the time of the initial stress resistance before bacterial decay.

The mixed model of two Weibull-type statistical distributions proposes that the survival patterns of cells can change with the physiological state of the cells and with how they adapt to stress. It assumes an initially large subpopulation that is more sensitive to stress (first part of the inactivation curve) and a smaller subpopulation that is more resistant to stress (second part of the curve). Its integrated rate equation is:

$\log N_{t}=\log \left(\frac{N_{o}}{1+10^{\alpha}}\left[10^{-\left(\frac{t}{\delta_{1}}\right)^{\mathrm{P}}+\propto}+10^{-\left(\frac{\mathrm{t}}{\delta_{2}}\right)^{\mathrm{P}}}\right]\right)$

Like the Weibull model, $\delta_{1}$ and $\delta_{2}$ parameters correspond to the time required to reduce the first logarithmic decimal cycle of the sensitive and resistant bacterial population, $p$ indicates the shape of the equation curve, and $\alpha$ is the fraction of the first subpopulation that remains of the total population, defined as $\alpha=\log (f /(1-f))$. This model fits sigmoidal curves when $\delta_{2}$ tends to infinity and tends to biphasic models when $p$ is close to unity and to linear models with tail when $\delta_{2}$ tends to infinity and $p$ to unity.

\section{Kinetic modeling of photolytic processes of Clostridium inactivation}

The inactivation kinetic curves describing the death of Clostridium vegetative cells and spores by photolytic treatments of wastewater effluent samples from Monleras macrophyte wetland were analyzed using four mathematical models: (1) the classical Chick-Watson model, (2) the 
Weibull distribution model, (3) the biphasic model (with tail or shoulder), and (4) the mixed double Weibull model. The classical model of exponential death will tell us if there is a homogeneous population or if there are deviations due to the different resistance of these microorganisms in their different forms. The Weibull distribution model will discriminate the type of curve, either concave or convex, fitting the kinetic data to the corresponding biphasic model curve with shoulder or tail. And finally, the mixed double Weibull model will confirm the type of model that fits the experimental inactivation kinetic curves. The joint count of spores and vegetative Clostridium species has been considered for the study of the kinetic mechanism. Figure 5 shows these fits together with the goodness-of-fit parameters for the wastewater samples. Error bars represent the standard deviation of experimental data.

\section{Chick and Watson Model}

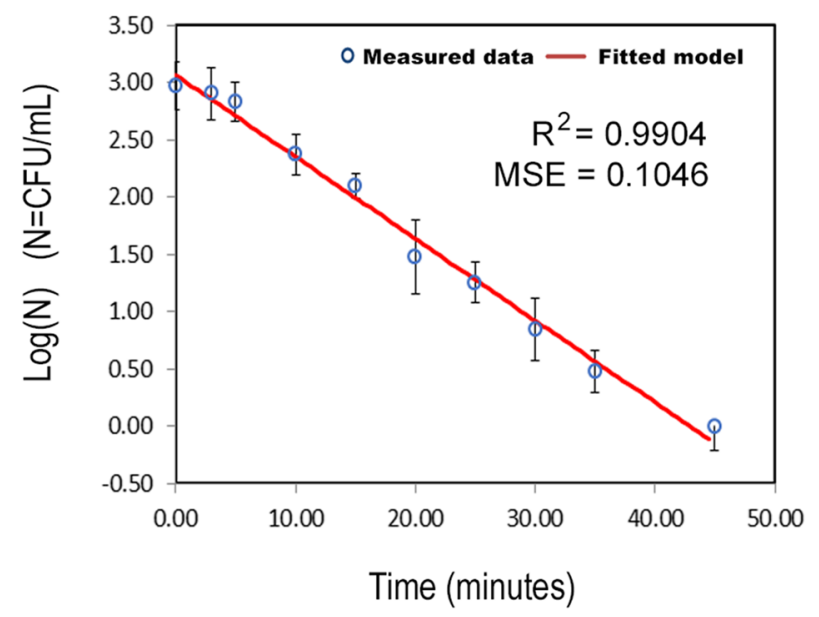

\section{Biphase model (shoulder or tailing )}

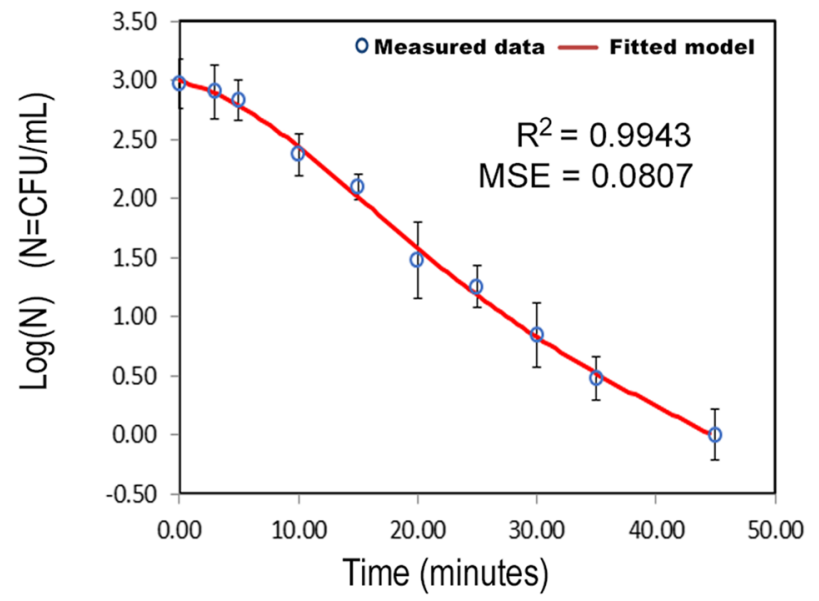

The values of the MSE (close to 0 ) and $R^{2}$ (very close to 1) indicators (Fig. 5), used to measure the goodness of each model fit, show, as a whole, a good fit of two proposed non-linear models (biphasic with shoulder and mixed double Weibull models) to the experimental microorganism inactivation data. However, the linear and Weibull models show an MSE value greater than 0.1 , which indicates a worse fit to experimental data by these two models show that there is not a homogeneous population that reacts to stress caused by the photolytic disinfecting action.

The kinetic and statistical parameters for each of the models fitted to the experimental kinetic data for Clostridium inactivation by photolysis in wastewater samples are shown in Table 1.

It is observed that the experimental kinetic curves are not fitted by a linear model but seem to fit a convex curve model,

\section{Weibull Distribution Model}

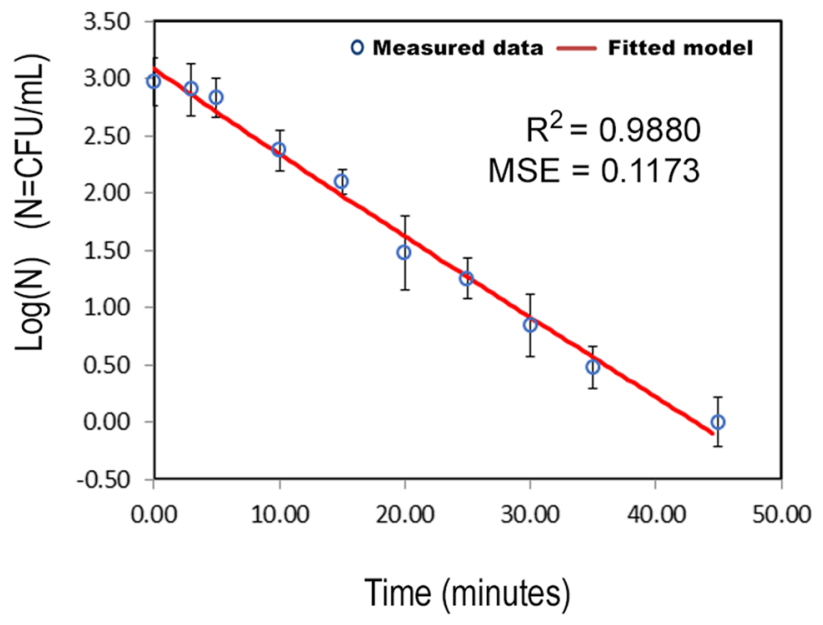

Doble Weibull Model

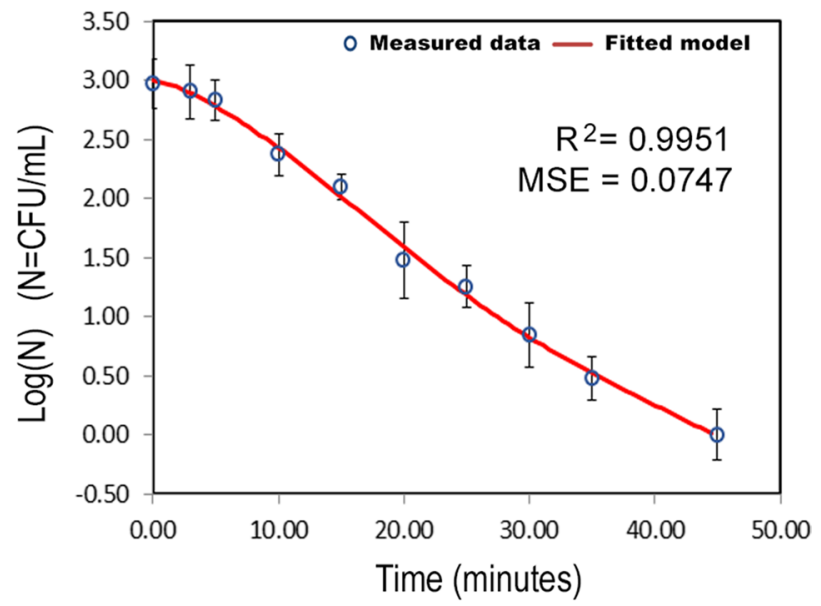

Fig. 5 Fits of the integrated rate equations of the models to the experimental kinetic data for Clostridium inactivation by photolysis 
Table 1 Kinetic and statistical parameters for the models fitted to the experimental kinetic data for Clostridium inactivation by photolysis

\begin{tabular}{|c|c|c|c|c|c|}
\hline \multirow[t]{2}{*}{ Chick-Watson model } & \multicolumn{5}{|l|}{$k\left(\min ^{-1}\right)$} \\
\hline & \multicolumn{5}{|l|}{$0.16 \pm 0.01$} \\
\hline \multirow[t]{2}{*}{ Weibull distribution model } & $p$ & $\delta_{1}(\min )$ & & & \\
\hline & $0.97 \pm 0.09$ & $13.5 \pm 1.6$ & & & \\
\hline \multirow[t]{2}{*}{ Biphasic model } & $k_{l}\left(\min ^{-1}\right)$ & $k_{2}\left(\min ^{-1}\right)$ & $f$ & & $\mathrm{~S}$ \\
\hline & $0.24 \pm 0.07$ & $0.11 \pm 0.05$ & $0.94 \pm 0.11$ & & $5.3 \pm 2.1$ \\
\hline \multirow[t]{2}{*}{ Double Weibull model } & $p$ & $\delta_{1}(\min )$ & $\delta_{2}(\min )$ & & $\alpha$ \\
\hline & $1.4 \pm 0.3$ & $14.5 \pm 1.2$ & $31.2 \pm 5.7$ & $1.3 \pm 0.4$ & \\
\hline
\end{tabular}

$p$ of the mixed double Weibull distribution model are greater than 1, so the curve of Clostridium inactivation by photolysis treatment was fitted to a biphasic model with shoulder. The difference of both rate constants (biphasic model) and $\delta$ values (mixed double Weibull model) indicates the presence of two Clostridium population groups, one resistant to UV radiation with an inactivation rate $k_{2}=0.11 \pm 0.05 \mathrm{~min}^{-1}$, the first part of the curve with a shoulder lasting $5.3 \pm 2.1 \mathrm{~min}$, and the second one, more sensitive to radiation with a $k_{1}=0.24 \pm 0.07 \mathrm{~min}^{-1}$. Thus, the first part of the curve (1- $f=6 \%$ ) shows the UV light irradiation resistant population $\left(k_{2}\right)$ during a period that marks the shoulder of $S=5.3 \mathrm{~min}$, followed by a rapid inactivation of the sensitive population $(f=94 \%)$. Finally, the mixed double Weibull model fit confirms a convex curve $(p=1.4 \pm 0.3)$ with two populations with a difference between them of $\alpha=1.3 \pm 0.4$ $\log$ units and with times needed to reduce the first decimal $\log$ cycle of the bacterial population of $\delta_{1}=14.5 \pm 1.2 \mathrm{~min}$ and $\delta_{2}=31.2 \pm 5.7 \mathrm{~min}$, respectively.

The difference in percentages between populations (sensitive and resistance) can be explained by the fact that stress suffered by Clostridium vegetative species, an anaerobic species, in the wastewater treatment of the Monleras WWTP, which primary treatment (Imhoff tank) has an anaerobic environment and the macrophyte ponds, with a facultative environment.

As indicated, UV radiation has a high bactericidal capacity on its own, producing severe injury in the cellular genetic material that result in an impediment to DNA replication and the generation of gene mutations, so this mechanism can be explained in vitalistic terms. Thus, initially (shoulder of the curve) radiation doses produce only a few lethal lesions and produce many sublethal lesions that are easily repaired. As increasing the time of the administered radiation dose, a greater number of lethal lesions are produced as a consequence of a greater accumulation of sublethal lesions, leading to a faster rate of cell inactivation. Other factors that could justify this shoulder effect, such as light irradiation power and light distribution in the reactor, are considered to have remained constant over time.

In morphological terms, the spore differs significantly from the vegetative cell, as it is composed in most cases of an outer surface envelope known as exosporium, followed inwards by the protein layers of the envelope and the cortex, which is made up of peptidoglycan, which the vegetative cell lacks (Mitchell 2001). As the cell wall is thicker in spores than in vegetative cells, the disinfection process according to this mechanism must be different for vegetative species (sensitive population) and spores (resistant population), the latter being more resilient. To verify this, samples subjected to photolytic treatment were taken after $100 \mathrm{~min}$, a period longer than that necessary for the reduction of 4 logarithmic cycles $(4 \delta)$ of microorganisms, which is the classical value considered as a guarantee of food preservation and food safety, hygiene, and quality conditions (Buchanan et al. 1993). After the samples were taken, seeding of the treated water was carried out, increasing the sensitivity of the method. For this purpose, $5 \mathrm{~mL}$ of sample was added to $5 \mathrm{~mL}$ of culture medium at double concentration instead of 1 to $9 \mathrm{~mL}$ of culture medium, and the Clostridium vegetative species and spores were identified, observing growth of $9 \pm 2 \mathrm{CFU}$, which indicates that the photolysis process is not effective for the total disinfection of water with presence of Clostridium. The presence of the bacteria in the aerobic lagoon opens up new perspectives, since the wild birds may be transporting Clostridium from one wetland to another (Long and Tauscher 2006).

\section{Kinetic modeling of photolytic processes of Coliforms inactivation}

Likewise, the inactivation kinetic curves of coliforms bacteria by photolytic treatments of wastewater samples were analyzed using the different mathematical models indicated (discrimination model). Figure 6 (total coliforms) and Fig. 7 (fecal coliforms) show these fits together with the goodnessof-fit parameters for the wastewater samples from Monleras WWTP.

In short inactivation times, the kinetics follow a log-linear-model; however, when inactivation was followed until times beyond $20 \mathrm{~min}$, it was found that these models demonstrate a better fit to the experimental data obtained, which are reflected in $R^{2}$ and MSE values better than those of the 
Chick and Watson Model

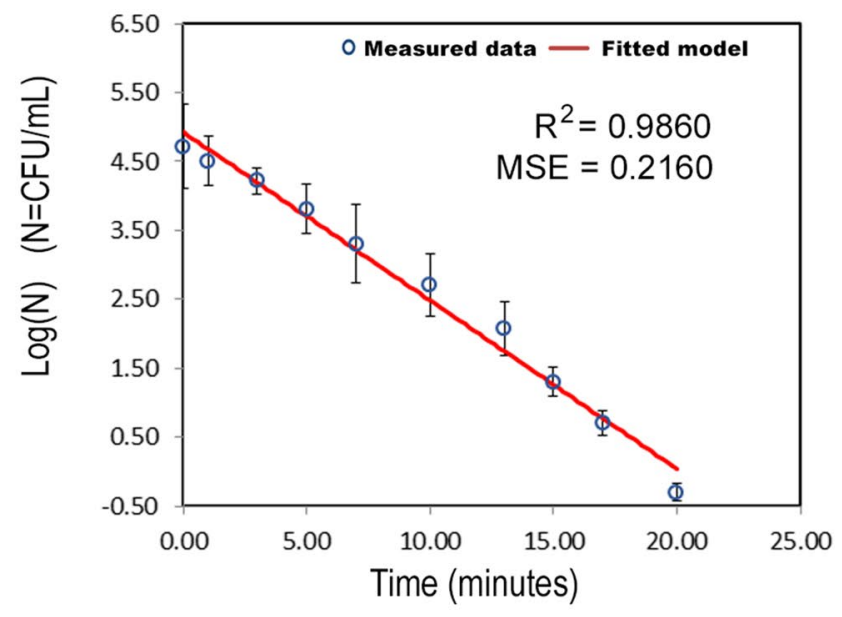

\section{Log Linear model (shoulder)}

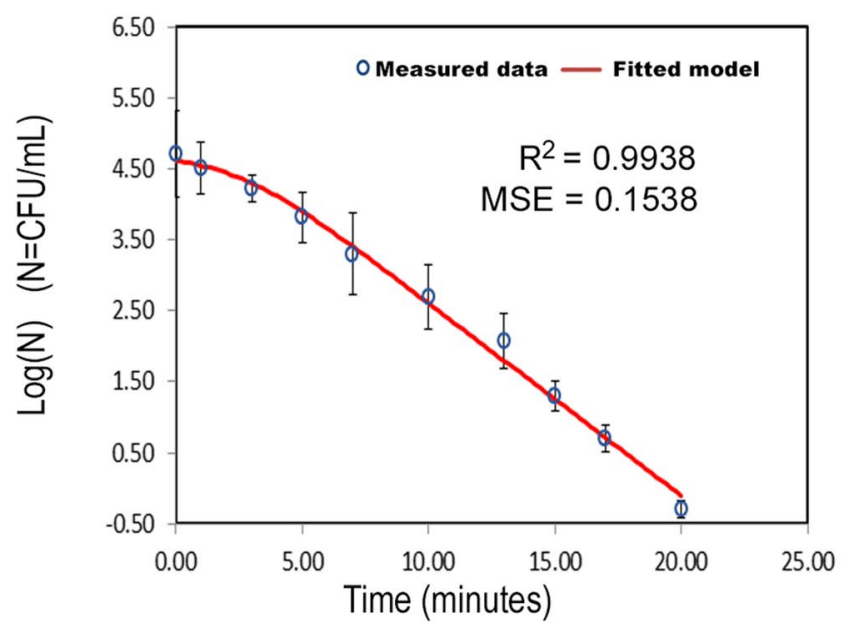

\section{Weibull Distribution Model}

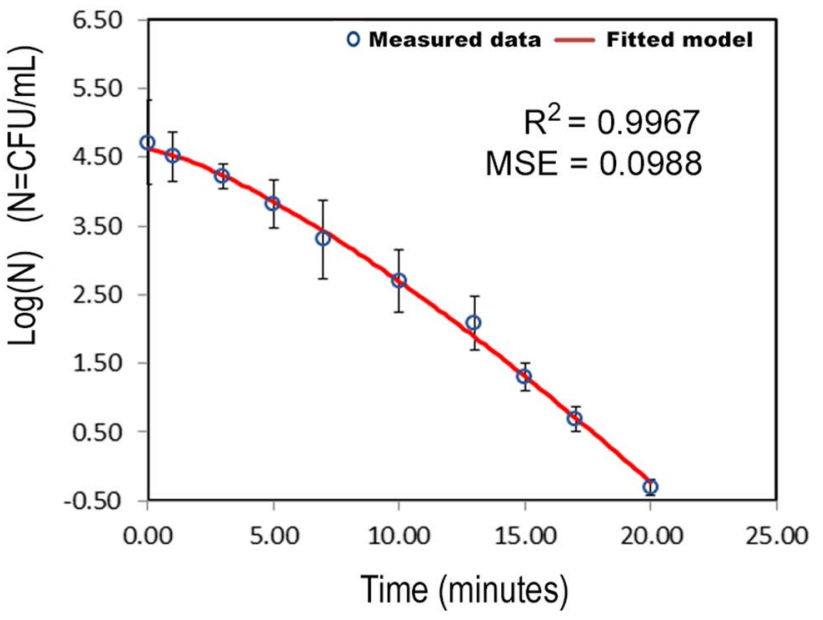

Doble Weibull Model

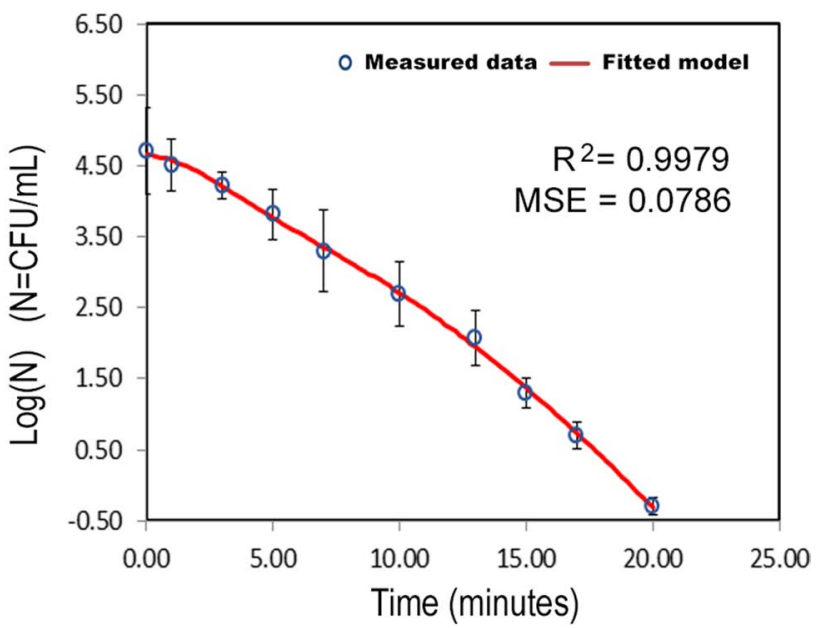

Fig. 6 Fits of the integrated rate equations of the models to the experimental kinetic data for total coliforms inactivation by photolysis

linear model (Fig. 6). The biphasic model does not show up in the fits, as despite having a good fit, the equality of the estimated inactivation constants $\left(k_{1}\right.$ and $\left.k_{2}\right)$ of the two populations indicates that the biphasic model is unlikely for these data.

The kinetic and statistical parameters for each of the models fitted to the experimental kinetic data for total coliforms inactivation by photolysis in wastewater samples are shown in Table 2.

On the one hand, statistical fitting confirms that the curve is convex ( $p=1.7 \pm 0.2)$ with two populations of coliforms with different physiological state. The time required to reduce the first logarithmic decimal cycle of the different types of bacteria (physiological states) are $\delta_{1}=4.2 \pm 0.9$ and $\delta_{2}=8.3 \pm 1.1 \mathrm{~min}$, respectively. According to the suggested model, total inactivation is reached at $17.4 \mathrm{~min}$.
On the other hand, it is observed that the best kinetic fit is to a logarithmic-linear model with a shoulder. Considering the hypothesis that there are two subgroups with different levels of resistance to stress coexist in a bacterial population, the first part of the curve shows the population resistance to electromagnetic radiation attack during the shoulder period $2.62 \pm 0.75 \mathrm{~min}$.

It was verified during the study time that the total elimination of coliforms in the maturation pond is not reached, which indicates that there is photoreactivation by sunlight.

Figure 7 shows these fits together with the goodness-of-fit parameters for fecal coliforms inactivation by photolysis in wastewater samples. Error bars represent the standard deviation of experimental data.

The kinetic and statistical parameters for each of the models fitted to the experimental kinetic data for fecal coliforms 
Chick and Watson Model

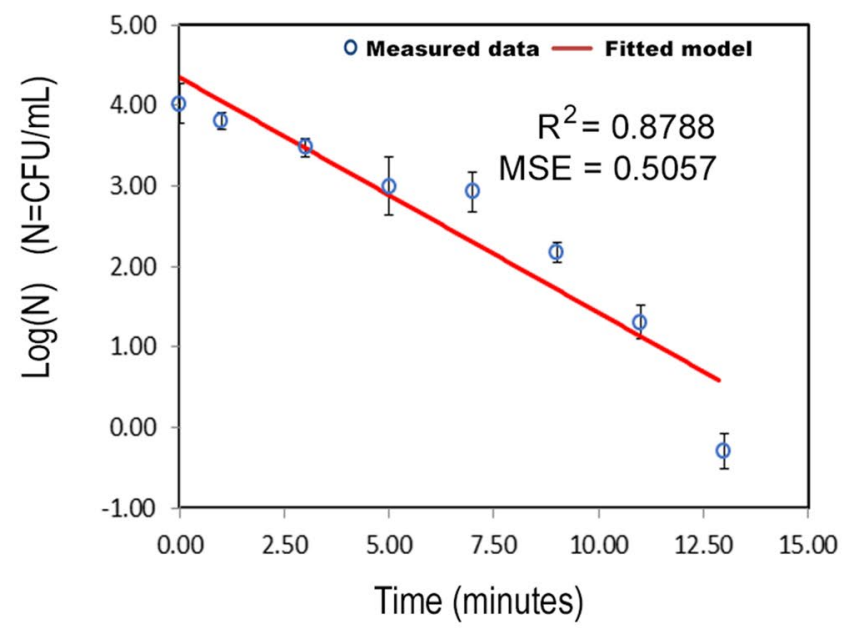

Log Linear model (shoulder)

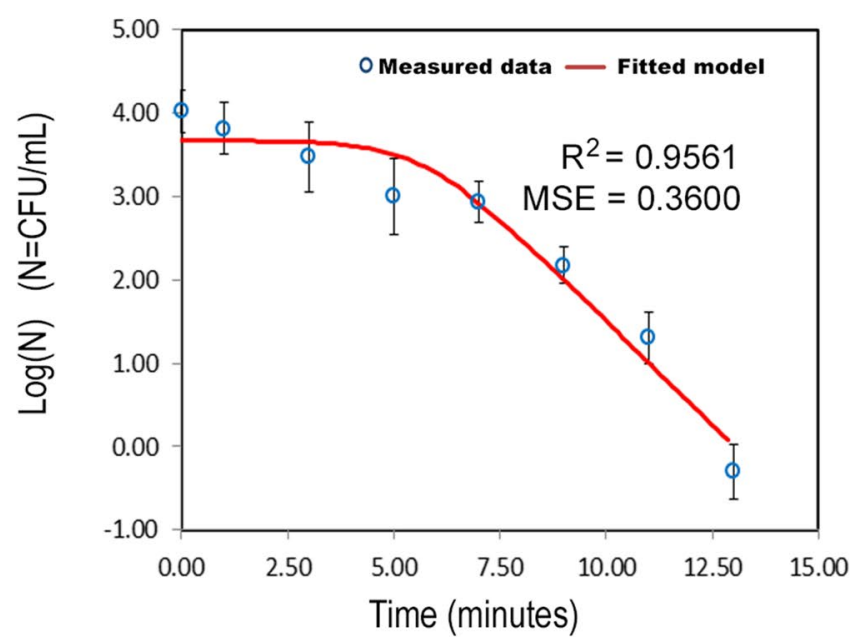

\section{Weibull Distribution Model}

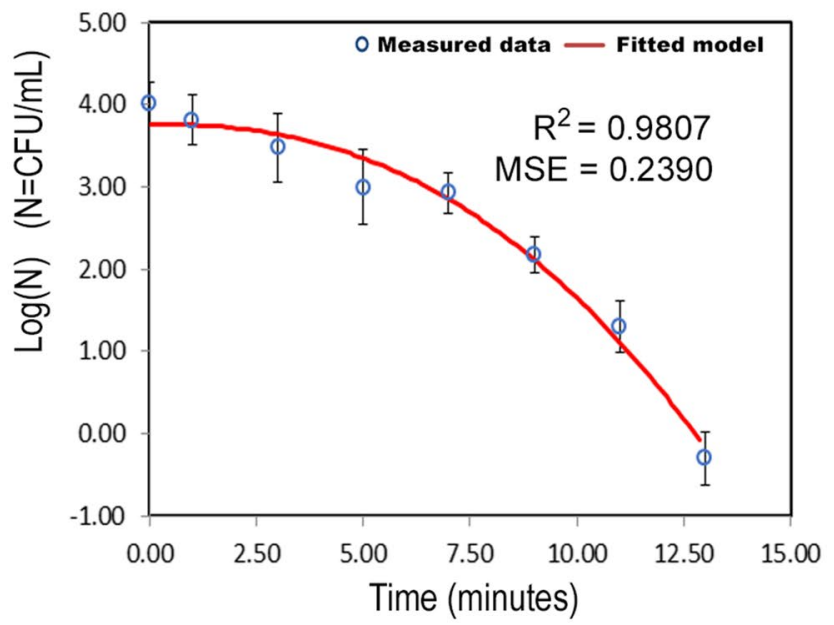

Doble Weibull Model

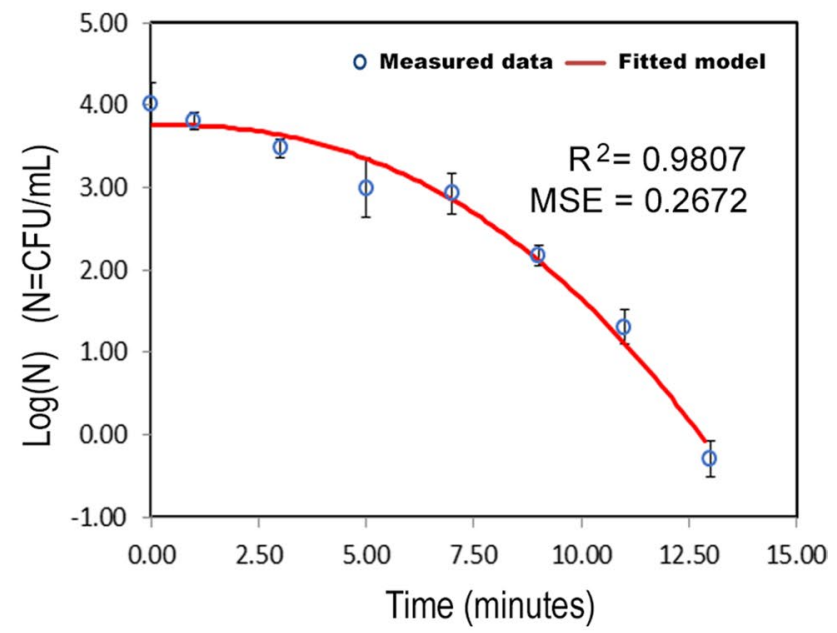

Fig. 7 Fits of the integrated rate equations of the models to the experimental kinetic data for Fecal Coliforms inactivation by photolysis

Table 2 Kinetic and statistical parameters for the models fitted to the experimental kinetic data for Total Coliforms inactivation by photolysis

\begin{tabular}{|c|c|c|c|c|}
\hline \multirow[t]{2}{*}{ Chick-Watson model } & \multicolumn{4}{|l|}{$k\left(\min ^{-1}\right)$} \\
\hline & \multicolumn{4}{|l|}{$0.56 \pm 0.02$} \\
\hline \multirow[t]{2}{*}{ Weibull distribution model } & $p$ & \multicolumn{3}{|l|}{$\delta_{1}(\min )$} \\
\hline & $1.33 \pm 0.07$ & \multicolumn{3}{|l|}{$6.11 \pm 0.37$} \\
\hline \multirow[t]{2}{*}{ Log Linear + shoulder model } & $k\left(\min ^{-1}\right)$ & $\mathrm{S}$ & \multicolumn{2}{|l|}{$4 \delta(\min )$} \\
\hline & $0.63 \pm 0.03$ & $2.62 \pm 0.75$ & \pm 17.4 & \\
\hline \multirow[t]{2}{*}{ Double Weibull model } & $p$ & $\delta_{1}(\min )$ & $\delta_{2}(\min )$ & $\alpha$ \\
\hline & $1.7 \pm 0.2$ & $4.2 \pm 0.9$ & $8.3 \pm 1.1$ & $0.43 \pm 0.36$ \\
\hline
\end{tabular}

inactivation by photolysis in wastewater samples are shown in Table 3.

The kinetic study of inactivation of fecal coliform bacteria indicates that, as in the study of total coliform bacteria, it fits a logarithmic-linear model with a shoulder, with a poor fit to the classical Chick-Watson model. It shows an initial electromagnetic radiation resistance (shoulder of the curve) with a duration of $5.7 \pm 1.0 \mathrm{~min}$ and an inactivation rate of $k=1.15 \pm 0.19 \mathrm{~min}^{-1}$. From a statistical point of view, no difference is observed between the Weibull 
Table 3 Kinetic and statistical parameters for the models fitted to the experimental kinetic data for Fecal Coliforms inactivation by photolysis

\begin{tabular}{lllll}
\hline Chick-Watson model & $k\left(\mathrm{~min}^{-1}\right)$ & & \\
& $0.67 \pm 0.09$ & & \\
Weibull distribution model & $p$ & $\delta_{1}(\min )$ & \\
& $2.4 \pm 0.4$ & $7.3 \pm 0.7$ & \\
Log Linear + shoulder model & $k\left(\min ^{-1}\right)$ & $\mathrm{S}$ & & \\
& $1.15 \pm 0.19$ & $5.7 \pm 1.0$ & & \\
Double Weibull model & $p$ & $\delta_{1}(\min )$ & $\delta_{2}(\min )$ & $\alpha$ \\
& $2.4 \pm 0.5$ & 7.3 & 7.3 & 4.32 \\
\hline
\end{tabular}

and double Weibull models, which seems to indicate that fecal coliform bacteria behave as a single population, with 7.3 min being the time needed to reduce the first logarithmic decimal cycle. In the inactivation of fecal coliform bacteria, the shoulder phase observed for a total coliform bacteria concentration $\left(\mathrm{N}_{\mathrm{o}}\right)$ with a very smooth decay is attributed to the loss of cell viability following the accumulation of damage during the photolytic process.

\section{Extrapolation of results from the photolytic reactor to the maturation lagoon}

In most of the works presented on the different types of constructed wetlands, emphasis has been placed on the study of the elimination of enteric bacteria such as fecal and total coliforms and Clostridium perfigens (Vymazal 2005), either by biological mechanisms such as competition for nutrients and exposure to inhibitory secretions of other bacteria (Stevik et al. 2004), virus-induced lysis (Fischer et al. 2006), and predation by protozoa (Decamp and Warren 1998) or by physical mechanisms, such as filtration and sedimentation as the main physical mechanisms for the removal of pathogenic microorganisms (Alufasi et al. 2017). In this work, we study the influence of chemical mechanisms such as UV solar radiation in real water maturation ponds (without vegetation) in a nature-based wastewater treatment.

In order to compare the results obtained by the photolytic process studied in the reactor and the inactivation processes of aerobic lagoons in the treatment plant, sampling and analysis of coliform and clostridium bacteria were carried out at different points of the treatment plant during the selected months. Samples were collected from the macrophyte wetland and from the tertiary wetland (both inside and at the outlet of the wetland). The average results are shown in Table 4.

The vegetative species of Clostridium and Coliforms bacteria were very low in the aerobic lagoon, due to the low vegetation and low water sheet, which favors the germicidal action of sunlight and therefore the elimination of these microorganisms. As can be seen, at the outlet of the maturation lagoon, the total elimination of coliform bacteria is not achieved, which may suggest processes of photo repair or bacterial photoreactivation.

According to the results of the inactivation kinetics obtained, both total coliform bacteria and total sulfite-reducing Clostridia can be approximated to the Chick-Watson model. In the case of fecal coliform bacteria, the first $10 \mathrm{~min}$ is considered in which the model has a linear behaviour. The population of a species of microorganism exposed to UV light is directly proportional to the intensity I of the radiation and the time $t$ of exposure. The differential rate equation of the Chick-Watson model (Chick 1908):

$\frac{\mathrm{N}_{\mathrm{t}}}{\mathrm{N}_{\mathrm{o}}}=\mathrm{e}^{-\mathrm{k}_{\mathrm{red}} \cdot \mathrm{It}}$

where $k_{\text {red }}$ is the reduction constant, $\left(\mathrm{cm}^{2} / \mathrm{mW} . \mathrm{s}\right), I$ is the ultraviolet germicidal irradiation (UVGI) $\left(\mathrm{mW} / \mathrm{cm}^{2}\right)$, and $t$ is the exposure time in seconds. The $k_{\text {red }}$ constant defines the microorganism sensitivity to UVGI and is unique for each species of microorganism under condition studied. The UVGI (Fig. 3) of $51 \mathrm{~mW} / \mathrm{cm}^{2}$ was considered. Figure 8 shows the determination of the microbial reduction constant for the bacteria studied.

Different reviews have shown that the removal of enteric bacteria occurs in different types of constructed wetlands at a high removal rate 75-99\% (Vymazal 2005; López et al. 2019), but the process is extremely slow with first order inactivation rate constants for E. coli $0.18 \mathrm{day}^{-1}$ at $22.8^{\circ} \mathrm{C}$ (Boutilier et al., 2009), for fecal coliforms $0.177 \mathrm{day}^{-1}$, for total coliforms $0.620 \mathrm{day}^{-1}$, and for Clostridium 0.102 day $^{-1}$ (Vymazal 2005). Solar disinfection is usually insignificant in
Table 4 Bacteriological analysis in wastewater treated by naturebased wastewater treatments

\begin{tabular}{|c|c|c|c|c|}
\hline & \multicolumn{2}{|c|}{ Macrophyte wetland } & \multicolumn{2}{|c|}{ Maturation lagoon } \\
\hline & $\begin{array}{l}\text { Inside } \\
(\mathrm{CFU} / 100 \mathrm{~mL})\end{array}$ & $\begin{array}{l}\text { Outlet } \\
(\mathrm{CFU} / 100 \mathrm{~mL})\end{array}$ & $\begin{array}{l}\text { Inside } \\
(\mathrm{CFU} / 100 \mathrm{~mL})\end{array}$ & $\begin{array}{l}\text { Outlet } \\
\text { (CFU/100 mL) }\end{array}$ \\
\hline Vegetative Clostridia & $950 \pm 350$ & $860 \pm 230$ & $5 \pm 3$ & $1 \pm 1$ \\
\hline Spore Clostridia & $35 \pm 10$ & $27 \pm 8$ & Not detected & Not detected \\
\hline Total Coliforms bacteria & $52 \pm 14.10^{4}$ & $37 \pm 17 \cdot 10^{4}$ & $520 \pm 30$ & $490 \pm 23$ \\
\hline Fecal Coliforms bacteria & $16 \pm 9.10^{4}$ & $11 \pm 9.10^{4}$ & $160 \pm 15$ & $120 \pm 16$ \\
\hline
\end{tabular}




\section{Chick and Watson Model}

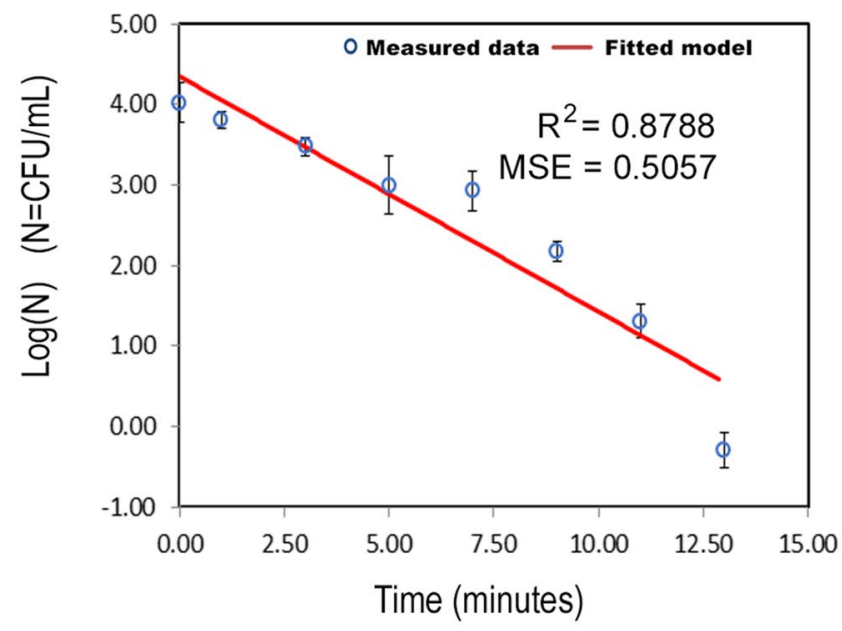

\section{Log Linear model (shoulder)}

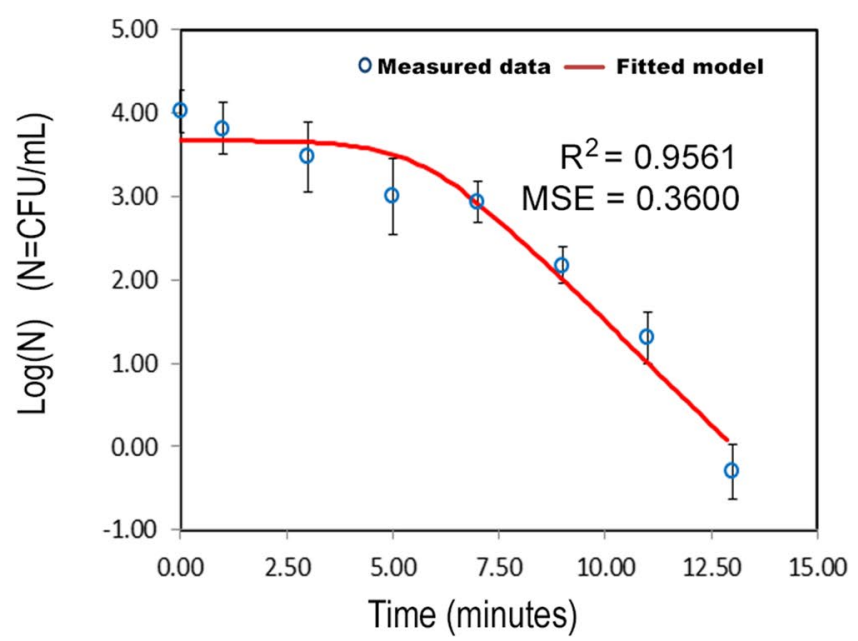

Fig. 8 Coliforms and Clostridium microbial reduction constants

vegetated wetlands due to shading by emergent macrophytes and floating vegetation (Kadlec and Wallace 2009). Recent studies have shown that solar exposure, during warmer seasons and in vegetation-free spaces, decreases by several logarithmic units for $E$. coli contamination in short periods of time (Schmidtlein et al. 2015; Vivant et al. 2016), obtaining values similar to this work in the elimination of enteric microorganisms in summer periods, expressed as a reduction of logarithmic units, thus for fecal coliforms of 2.0 Ulog in maturation lagoons and 2.5 Ulog in UV systems, for total coliforms of $1.8 \mathrm{Ulog}$ in maturation lagoons and 2.9 Ulog in UV systems and for Clostridium of 0.1 Ulog in maturation lagoons and 0.2 Ulog in UV systems (Russo et al. 2019). Furthermore, other authors such as Nguyen et al. (2015) demonstrated that the comparison of vegetated versus pilotscale open water wetlands seems to provide higher rates of

\section{Weibull Distribution Model}

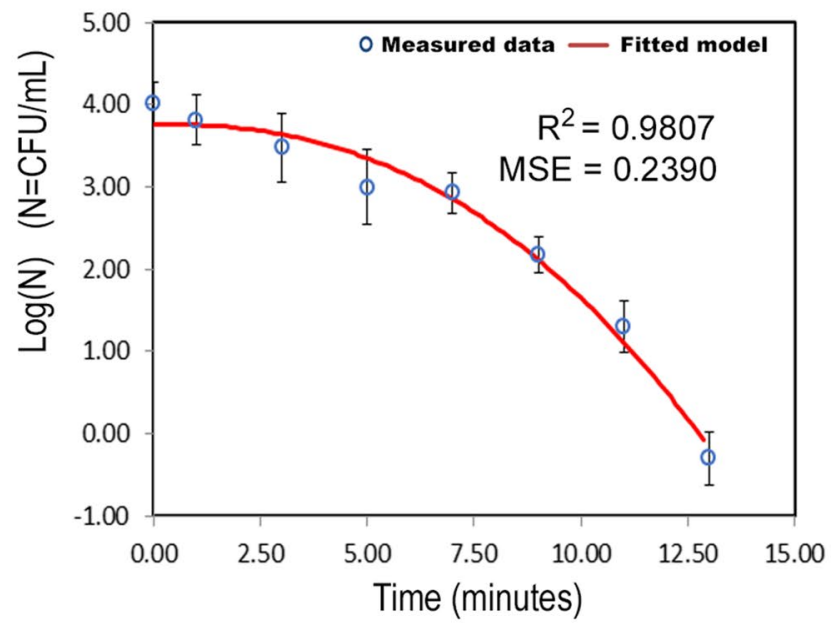

Doble Weibull Model

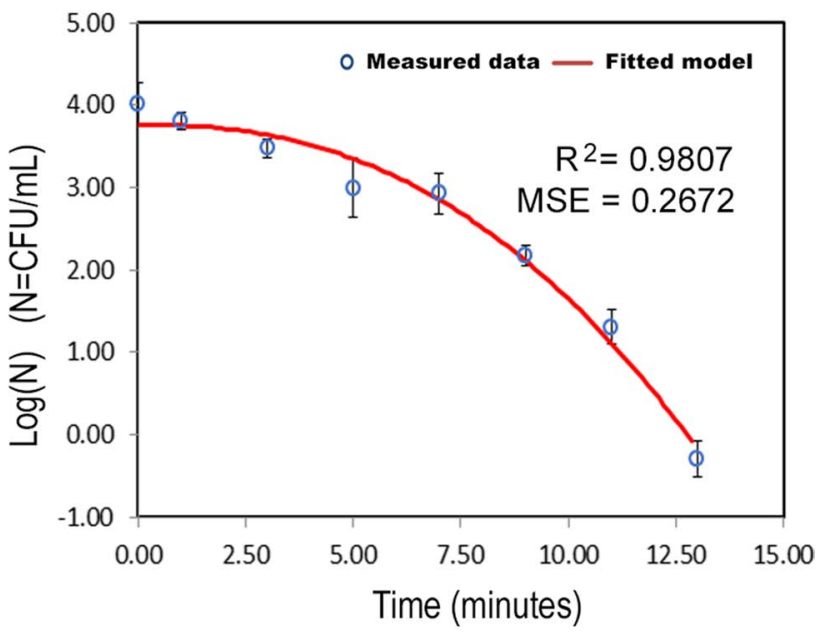

bacterial indicator removal ( $E$. coli inactivation rate constant $k=2.9 \mathrm{day}^{-1}$ in winter and $k=7.0 \mathrm{day}^{-1}$ in summer), mainly through sunlight-mediated inactivation.

The microbicidal action depends on the radiation intensity and the dose applied. The UV dose corresponds to the product of the intensity by the time $\left(\mathrm{mW} . \mathrm{s} / \mathrm{cm}^{2}\right)$. According to the values obtained for the microbial reduction constant in the photolytic reactor lamp for these species, the bacteriological analysis in wastewater treated by nature-based wastewater treatments (Table 5), and the average radiation intensity during the months of May to July was $31.6 \mathrm{~mW} / \mathrm{cm}^{2}$, the inactivation time was calculated for maturation lagoon. The inactivation time in photolytic reactor is the time necessary

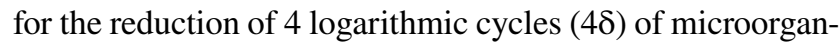
isms, while the inactivation time for the maturation lagoon is calculated as a function of the bacterial reduction from 
Table 5 Dose applied for the inactivation of different types of bacteria

\begin{tabular}{llllll}
\hline & \multicolumn{2}{l}{ Photolytic reactor } & & \multicolumn{2}{l}{ Maturation lagoon } \\
\cline { 2 - 3 } \cline { 5 - 6 } & $\begin{array}{l}\text { Inactivation } \\
\text { time } \\
\text { (minutes) }\end{array}$ & $\begin{array}{l}\text { Dose applied } \\
\mathrm{mW} . \mathrm{s} / \mathrm{cm}^{2}\end{array}$ & & $\begin{array}{l}\text { Inactivation } \\
\text { time } \\
(\text { minutes })\end{array}$ & $\begin{array}{l}\text { Dose applied } \\
\mathrm{mW} . \mathrm{s} / \mathrm{cm}^{2}\end{array}$ \\
\hline Clostridia bacteria & 58 & & 65.8 & 124,716 \\
Total Coliforms bacteria & 24.4 & 74,664 & & 18.9 & 35,799 \\
Fecal Coliforms bacteria & 29.2 & 89,352 & & 20.9 & 39,756 \\
\hline
\end{tabular}

the macrophyte wetland outlet and the maturation lagoon outlet, not reaching total water disinfection. Table 5 shows this extrapolation for the maturation lagoon.

The efficacy of disinfection (UV dose applied for bacterial load reduction) will depend on several factors including turbidity and organic matter concentration, so the dose applied will depend on the nature of the water (Carré et al. 2018). Authors have reported lower applied dose values than those reported in this paper for coliform bacteria, but these were not extrapolated to total inactivation and used samples that had been filtered or centrifuged prior to UV dosing, such as water from salmonid culture system with an average UV dose of $1821 \pm 86 \mathrm{~mW} \mathrm{~s} / \mathrm{cm}^{2}$ for a $98 \%$ reduction (Sharrer et al. 2005) or swine wastewater lagoons with 700 to 2400 $\mathrm{mW} \mathrm{s} / \mathrm{cm}^{2}$ (Macauley et al. 2006), while in the current work, the samples have not been pre-treated.

The results obtained confirm the photolytic disinfection processes, and the maturation lagoon are effective systems for Clostridia bacteria removal after water treatment by nature-based systems. Total removal of coliform bacteria is not achieved by maturation lagoons, but their reduction is significant using low doses of cumulative radiation.

\section{Conclusions}

The inactivation kinetic curves of Clostridium bacteria by photolysis fits well in a biphasic model with a shoulder, compatible with two populations, a first resistant one (shoulder of the curve) and a second sensitive one (second part of the curve). This model would be interpreted in terms of a radiation attack on the DNA of the bacterial cell: initially the bacteria would be resistant to radiation, resulting in only a few lethal lesions and many sublethal lesions that would be easily repaired, but as the time of the radiation dose administered is increased, a greater number of lethal lesions would occur, due to more accumulation of sublethal lesions, leading to a faster rate of cell inactivation. It is observed that the Clostridium corresponds almost entirely to the sensitive population ( $94 \%$ ); this may be due to the fact that the anaerobic and facultative pre-treatment conditions favor the non-formation of spores.
In wastewater after nature-based treatment, the photolytic processes of inactivation of Coliform bacteria are faster than those of Clostridia bacteria. Regarding total coliform bacteria, there appear to be two populations with different resistance to stress due to the different physiological states of the bacteria, whereas there is only one population for fecal coliform bacteria.

The extrapolation of the results obtained for the bacterial reduction constants in the photolytic reactor to the maturation lagoons concludes that lower applied UV doses are required to reduce bacterial contamination in these lagoons, being effective systems to reduce bacterial contamination after water treatment by nature-based systems, although complete disinfection is not achieved. Therefore, when implementing this type of low-cost natural treatment for wastewater disinfection, it is the cumulative dose of ultraviolet radiation, and not the treatment time, that should be considered the most important factor. In this sense, with an adequate pre-treatment and maintenance of the plant, low vegetation, and water level in the maturation lagoon, a good performance of disinfection of the wastewater can be obtained, even in the months less favorable for UV radiation due to that during such periods of time a lower organic load enters the maturation lagoons of such nature-based WWTPs, which generally exist in small towns in rural areas, as a consequence of the population seasonality of those municipalities, being necessary a lower radiation dose to reach the bacterial inactivation.

Acknowledgements The authors thank Monleras Town Council for allowing the collection of wastewater samples from its WWTP to carry out this work.

Author contribution José Bernardo Proal-Nájera and Manuel GarcíaRoig designed the study; Juan Carlos García-Prieto and Cynthia Manuela Núñez-Núñez conducted the experimental work and the fitting and modeling of data; Juan Carlos García-Prieto and Manuel García-Roig wrote the paper. All authors read and approved the final manuscript.

Funding Open Access funding provided thanks to the CRUE-CSIC agreement with Springer Nature.

Data availability All data of this study can be obtained from the corresponding author according to appropriate requirements. 


\section{Declarations}

Ethics approval Not applicable.

Consent to participate Not applicable.

Consent to publish Not applicable.

Competing interests The authors declare no competing interests.

Open Access This article is licensed under a Creative Commons Attribution 4.0 International License, which permits use, sharing, adaptation, distribution and reproduction in any medium or format, as long as you give appropriate credit to the original author(s) and the source, provide a link to the Creative Commons licence, and indicate if changes were made. The images or other third party material in this article are included in the article's Creative Commons licence, unless indicated otherwise in a credit line to the material. If material is not included in the article's Creative Commons licence and your intended use is not permitted by statutory regulation or exceeds the permitted use, you will need to obtain permission directly from the copyright holder. To view a copy of this licence, visit http://creativecommons.org/licenses/by/4.0/.

\section{References}

AEMET. Agencia Estatal de Meteorología. http://www.aemet. es/. Accessed January - December 2020

AENOR (2009) Calidad del Agua 4. ${ }^{a}$ Edición. CD-ROM. ISBN 9788481436365

Almuktar SAAAN, Abed SN, Scholz M (2018) Wetlands for wastewater treatment and subsequent recycling of treated effluent: a review. Environ Sci Pollut Res 25:23595-23623. https://doi.org/ 10.1007/s11356-018-2629-3

Alufasi R, Gere J, Chakauya E, Lebea PJ, Parawira W, Chingwaru W (2017) Mechanisms of pathogen removal by macrophytes in constructed wetlands. Environ Technol Rev 6(1):135-144. https:// doi.org/10.1080/21622515.2017.1325940

Ando Y, Tsuzuki T (1986) The effect of hydrogen peroxide on spores of Clostridium perfringens. Lett Appl Microbiol 2:65-68. https:// doi.org/10.1111/j.1472-765X.1986.tb01517.x

APHA (1995) 9215 B. Pour plate method. In: Eaton AD, Clesceri LS, Greenberg AE (eds) Standard methods for the examination of water and wastewater. APHA, Washington

Arco-Alaínez M (2014) Memoria explicativa del filtro verde y el humedal. Centro de Interpretación del Bajo Tormes Ayuntamiento de Monleras, España

Ashbolt NJ, Grabow WOK and Snozzi M (2001) World Health Organization (WHO). Water Quality: Guidelines, Standards and Health. Edited by Lorna Fewtrell and Jamie Bartram. Published by IWA Publishing, London, UK. ISBN: 1900222280

Azaizeh H, Linden K, Barstow C, Kalbouneh S, Tellawi A, Albalawneh A, Gerchman Y (2013) Constructed wetlands combined with UV disinfection systems for removal of enteric pathogens and wastewater contaminants. Water Sci Technol 67(3):651-657. https:// doi.org/10.2166/wst.2012.615

Bardsley WG (2017) Simfit Statistical package. v. 7.3.1 Academic 64-bit Manchester University UK. http://www.simfit.man.ac.uk. Accessed September 2017

Bolton JR, Linden KG (2003) Standarization of methods for fluence (UV Dose). Determination in bench-scale UV experiments. J Environ Eng 129:209-215. https://doi.org/10.1061/(ASCE)07339372(2003)129:3(209)
Boutilier L, Jamieson R, Gordon R, Lake C, Hart W (2009) Adsorption sedimentation and inactivation of E. coli within wastewater treatment wetlands. Water Research 43(17):4370-4380. https:// doi.org/10.1016/j.watres.2009.06.039

Buchanan RL, Golden MH, Whiting RC (1993) Differentiation of the effects of $\mathrm{pH}$ and lactic or acetic acid concentration on the kinetics of Listeria monocytogenes inactivation. J Food Prot 56:474-478. https://doi.org/10.4315/0362-028X-56.6.474

Carré E, Pérot J, Jauzein V, Lopez-Ferber M (2018) Impact of suspended particles on UV disinfection of activated-sludge effluent with the aim of reclamation. Journal of Water Process Engineering 2287-93. https://doi.org/10.1016/j.jwpe.2018.01.016

Cerf O (1977) A review. Tailing of survival curves of bacterial spores. J Appl Microbiol 42:1-19. https://doi.org/10.1111/j.1365-2672. 1977.tb00665.x

Chick H (1908) An investigation into the laws of disinfection. J Hyg (lond) 8:92-158. https://doi.org/10.1017/s0022172400006987

Cho M, Chung H, Choi W, Yoon J (2004) Linear correlation between inactivation of $E$. coli and $\mathrm{OH}$ radical concentration in $\mathrm{TiO} 2$ photocatalytic disinfection. Water Res 38(4):1069-77. https://doi.org/ 10.1016/j.watres.2003.10.029

Coroller L, Leguérinel I, Mettler E, Savy N, Mafart P (2006) A general model based on two mixed Weibull distributions of bacterial resistance, for fitting various shapes of inactivation curves. Appl Environ Microbiol 72:6493-6502. https://doi.org/10.1128/AEM. 00876-06

Dalrymple OK, Stefanakos E, Trotz MA, Goswami DY (2010) A review of the mechanisms and modeling of photocatalytic disinfection. Appl Catal b: Environ 98:27-38. https://doi.org/10.1016/j. apcatb.2010.05.001

Decamp O, Warren A (1998) Bacterivory in ciliates isolated from constructed wetlands (reed beds) used for wastewater treatment. Water Research 32(7):1989-1996. https://doi.org/10.1016/S00431354(97)00461-2

Dekker J, Frank K (2015) Salmonella, Shigella, and Yersinia. Clin Lab Med 35(2):225-246. https://doi.org/10.1016/j.cll.2015.02.002

Dolin MI (1959) Oxidation of reduced diphosphopyridine nucleotide by Clostridium perfringens. I. Relation of Peroxide to the overAll Reaction. J Bacteriol 77:383-392. https://doi.org/10.1128/JB. 77.4.383-392.1959

Downes A, Blunt TP (1877) Researches on the effect of light upon bacteria and other organisms. Proc Royal Soc b 26:488-500. https:// doi.org/10.1098/rspl.1877.0068

Dunlop PSM, McMurray TA, Hamilton JWJ, Byrne JA (2008) Photocatalytic inactivation of Clostridium perfringens spores on $\mathrm{TiO}_{2}$ electrodes. J Photochem Photobiol a: Chem 196:113-119. https:// doi.org/10.1016/j.jphotochem.2007.11.024

Fischer UR, Wieltschnig C, Kirschner AKT, Velimirov B (2006) Contribution of virus-induced lysis and protozoan grazing to benthic bacterial mortality estimated simultaneously in microcosms. Environmental Microbiology 8(8):1394-1407. https://doi.org/10. 1111/j.1462-2920.2006.01032.x

García-Prieto JC, Cachaza Silverio JM (2008) Reutilización y Depuración Sostenible de Aguas Residuales en Pequeños Municipios Ejemplos: Municipios de Villavieja de Yeltes y Monleras. Tecnoambiente 186:27-30

Geeraerd AH, Herremans CH, Van Impe JF (2000) Structural model requirements to describe microbial inactivation during a mild heat treatment. Int J Food Microbiol 59(3):185-209

Geeraerd AH, Valdramidis VP, Van Impe JF (2005) GInaFiT, a freeware tool to assess non-log-linear microbial survivor curves. Int J Food Microbiol 102:95-105. https://doi.org/10.1016/j.ijfoodmicro.2004.11.038

Gomes AI, Santos JC, Vilar VJP, Boaventura RAR (2009) Inactivation of bacteria $E$. coli and photodegradation of humic acids using 
natural sunlight. Appl Catal B Environ 88:283-291. https://doi. org/10.1016/j.apcatb.2008.11.014

González Y, Salgado P, Vidal G (2019) Disinfection behavior of a UVtreated wastewater system using constructed wetlands and the rate of reactivation of pathogenic microorganisms. Water Sci Technol 80(10):1870-1879. https://doi.org/10.2166/wst.2020.007

Gorchev HG and Ozolins G (1984) WHO guidelines for drinking-water quality WHO Chron 38: 104-108

Groocock NH (1984) Disinfection of drinking water by ultraviolet light. J Institut Water Engineers \& Scientists 38:163-172

Guo M, Huang J, Hu H, Liu W, Yang J (2013) Quantitative characterization and prediction modeling of photoreactivation of coliforms after ultraviolet disinfection of reclaimed municipal wastewater. Water Air Soil Pollut 224(11):1774. https://doi.org/10.1007/ s11270-013-1774-z

Gyürek LL, Finch GR (1998) Modeling water treatment chemical disinfection kinetics. J Environ Eng 124:783-793. https://doi.org/10. 1061/(ASCE)0733-9372(1998)124:9(783)

Heaselgrave W, Kilvington S (2010) Antimicrobial activity of simulated solar disinfection against bacterial, fungal and protozoan pathogens and its enhancement by riboflavin. Appl Environ Microbiol 76(17):6010-6012. https://doi.org/10.1128/AEM. 00445-10

Hom LW (1972) Kinetics of chlorine disinfection in an ecosystem. J Sanit Eng Div 98:183-193. https://doi.org/10.1061/JSEDAI. 0001370

Huang Y, Truelstrup Hansen L, Ragush CM, Jamieson RC (2018) Disinfection and removal of human pathogenic bacteria in arctic waste stabilization ponds. Environ Sci Pollut Res 25:3288132893. https://doi.org/10.1007/s11356-017-8816-9

Josset S, Keller N, Lett MC, Ledoux MJ, Keller V (2008) Numeration methods for targeting photoactive materials in the UV-A photocatalytic removal of microorganisms. Chem Soc Rev 37:744-755. https://doi.org/10.1039/b711748p

Kadlec R, Wallace S (2009) Treatment wetlands. CRC Press, Boca Raton

Khaengraeng R, Reed RH (2005) Oxigen and photoinactivaction of Escherichia coli in UVA and sunlight. J Appl Microbiol 99:39-50. https://doi.org/10.1111/j.1365-2672.2005.02606.x

Koninklijke Philips N.V. https://www.lighting.philips.com/. Accessed May 2021

Lanao M, Ormad MP, Goñi P, Miguel N, Mosteo R, Ovelleiro JL (2010) Inactivation of Clostridium perfringens spores and vegetative cells by photolysis and $\mathrm{TiO}_{2}$ photocatalysis with $\mathrm{H}_{2} \mathrm{O}_{2}$. Sol Energy 84:703-709. https://doi.org/10.1016/j.solener.2010.01.023

López D, Leiva AM, Arismendi W, Vidal G (2019) Influence of design and operational parameters on the pathogens reduction in constructed wetland under the climate change scenario. Rev Environ Sci Biotechnol 18(1):101-125. https://doi.org/10.1007/ s11157-019-09493-1

Long SC, Tauscher T (2006) Watershed issues associated with Clostridium botulinum: a literature review. J Water Health 4(3):277-288. https://doi.org/10.2166/wh.2006.016b

Lorch W (1987) Handbook of Water Purification 2nd. ed. Chichester, UK: Ellis Horwood. https://doi.org/10.1002/aheh.19880160409

Mafart P, Couvert O, Gaillard S, Leguerinel I (2002) On calculating sterility in thermal preservation methods: application of the Weibull frequency distribution model. Int J Food Microbiol 72:107-113. https://doi.org/10.1016/S0168-1605(01)00624-9

Masi F, Martinuzzi N (2007) Constructed wetlands for the Mediterranean countries: hybrid systems for water reuse and sustainable sanitation Desalination 215. Issues 1-3(5):44-55. https://doi.org/ 10.1016/j.desal.2006.11.014

Masschelein WJ, Rice RP (2002) Ultraviolet light in water and wastewater sanitation. Ed. R.P. Rice. CRC Press, Boca Raton, Florida.
ISBN 1-56670-603-3, pp 174, https://doi.org/10.1201/97814 20032178.

Mitchell WJ (2001) Clostridia: biotechnology and medical applications. In: Bahl H, Dürre P (eds) General Biology and Physiology. Wiley- VCH Verlag, Weinheim, pp 72-83

Nan X, Lavrnić S, Toscano A (2020) Potential of constructed wetland treatment systems for agricultural wastewater reuse under the EU framework. J Environ Manage 1(275):111219. https://doi.org/10. 1016/j.jenvman.2020.111219

Nguyen MT, Jasper JT, Boehm AB, Nelson KL (2015) Sunlight inactivation of fecal indicator bacteria in open-water unit process treatment wetlands: Modeling endogenous and exogenous inactivation rates. Water Research 83282-292. https://doi.org/10.1016/j. watres.2015.06.043

Oh EJ, Kim JM and Kim, JK (2021) Interrelationship between climatic factors and incidence of FBD caused by Clostridioides difficile toxin B, Clostridium perfringens, Campylobacter spp., and Escherichia coli O157:H7. Environ Sci Pollut Res. https:// doi.org/10.1007/s11356-021-13854-1

Park MS, Park KH, Bahk GJ (2018) Combined influence of multiple climatic factors on the incidence of bacterial foodborne diseases. Sci Total Environ 610-611:10-16. https://doi.org/10.1016/j.scito tenv.2017.08.045

Payment P (1999) Poor efficacy of residual chlorine disinfectant in drinking water to inactivate waterborne pathogens in distribution systems. Can J Microbiol 45:709-715. https://doi.org/10.1139/ w99-063

Rahman MdE, Eendi Bin Halmi MI, Bin AbdSamad MY, Uddin MdK, Mahmud K, Abd Shukor MY, Abdullah SRS, Shamsuzzaman SM (2020) Design, operation and optimization of constructed wetland for removal of pollutant. Int J Environ Res Public Health 17:8339. https://doi.org/10.3390/ijerph17228339

Russo N, Marzo A, Randazzo C, Caggia C, Toscano A, Cirelli GL (2020) Constructed wetlands combined with disinfection systems for removal of urban wastewater contaminants. Sci Total Environ 656:558-566. https://doi.org/10.1016/j.scitotenv.2018.11.417

Russo N, Marzo A, Randazzo C, Caggia C, Toscano A, Cirelli GL (2019) Constructed wetlands combined with disinfection systems for removal of urban wastewater contaminants. Science of The Total Environment 656558-566. https://doi.org/10.1016/j.scito tenv.2018.11.417

Schmidtlein F, Lübken M, Grote I, Orth H, Wichern M (2015) (2014) Photoreactivation and subsequent solar disinfection of Escherichia coli in UV-disinfected municipal wastewater under natural conditions. Water Science and Technology 71(2):220-226. https://doi. org/10.2166/wst.2014.488

Stevik TK, Aa K, Ausland G, Hanssen JF (2004) Retention and removal of pathogenic bacteria in wastewater percolating through porous media: a review. Water Research 38(6):1355-1367. https://doi. org/10.1016/j.watres.2003.12.024

Talukdar PK, Udompijitkul P, Hossain A, Sarker MR (2016) Inactivation strategies for Clostridium perfringens Spores and Vegetative Cells. Appl Environ Microbiol 83(1):1-13. https://doi.org/10. 1128/AEM.02731-16

Tanner CC, Craggs RJ, Sukias JPS, Park JBK (2005) Comparison of maturation ponds and constructed wetlands as the final stage of an advanced pond system. Water Sci Technol 51(12):307-314. https://doi.org/10.2166/wst.2005.0489

Rincón AG, Pulgarin C (2004) Bactericidal action of illuminated $\mathrm{TiO}_{2}$ on pure Escherichia Coli and natural bacterial consortia: postirradiation events in the dark and assessment of the effective disinfection time. Appl Catal B 49:99-112

Rincón AG, Pulgarin C (2007) Solar photolytic and photocatalytic disinfection of water at laboratory and field scale. Effect of the chemical composition of water and study of the postirradiation 
events. J Sol Energy Eng 129(1):100-110. https://doi.org/10. $1115 / 1.2391308$

Venczel LV, Arrowood M, Hurd M, Sobsey MD (1997) Inactivation of Cryptosporidium parvum oocysts and Clostridium perfringens spores by a mixed-oxidant disinfectant and by free chlorine. Appl Environ Microbiol 63:1598-1601. https://doi.org/10.1128/AEM. 63.4.1598-1601.1997

Vivant A-L, Boutin C, Prost-Boucle S, Papias S, Hartmann A, Depret G, Ziebal C, Le Roux S, Pourcher A-M (2016) Free water surface constructed wetlands limit the dissemination of extendedspectrum beta-lactamase producing Escherichia coli in the natural environment. Water Research 104178-188. https://doi.org/10. 1016/j.watres.2016.08.015

Vymazal J (2005) Removal of enteric bacteria in constructed treatment wetlands with emergent macrophytes: a review. J Environ Sci Health A Tox Hazard Subst Environ Eng 40(6-7):1355-67. https://doi.org/10.1081/ese-200055851
Watts RJ, Kong S, Orr MP, Miller GC, Henry BE (1995) Photocatalytic inactivation of coliform bacteria and viruses in secondary wastewater effluent. Water Res 29(1):95-100. https://doi.org/10.1016/ 0043-1354(94)E0122-M

WHO (2011) Evaluation household water treatment options: health-based targets and microbiological performance specifications. https://apps.who.int/iris/handle/10665/44693. Accessed May 2021

Wu S, Carvalho PN, Müller JA, Manoj VR, Dong R (2016) Sanitation in constructed wetlands: a review on the removal of human pathogens and fecal indicators. Sci Total Environ 541:8-22. https://doi. org/10.1016/j.scitotenv.2015.09.047

Publisher's note Springer Nature remains neutral with regard to jurisdictional claims in published maps and institutional affiliations. 